\title{
Profitabilitas Biodiesel dari Biomasa Mikroalga
}

\section{Biodiesel Profitability of Microalgae Biomass}

\author{
LESTARIO WIDODO, IIF MIFTAHUL IHSAN, DAN ARIF DWI SANTOSO* \\ Pusat Teknologi Lingkungan - Badan Pengkajian dan Penerapan Teknologi \\ Gedung Geostech 820, Puspiptek Serpong 15314, Indonesia \\ arif.dwi@bppt.go.id
}

\begin{abstract}
In order to reduce dependence on fossil fuels especially oil, the Government of Indonesia has targeted the use of biofuel such as bioethanol and biodiesel as many as $5 \%$ in 2025 . The obstacles in the development of biofuels is the competition of biofuel raw materials to the food provision, limitations in terms of facilities and infrastructures, and other non-technical obstacles such as fluctuation in world crude oil prices. If the world's crude oil price rises, then this condition will positively encourage energy diversification efforts including for biofuels, and also vice versa. In this study, the calculation of biofuel (biodiesel) productivity is made and then it is compared with the world price of crude oil. In addition, it is also analyzed efforts to increase the profitability value of microalgae biodiesel by increasing the efficiency of productivity through the utilization of waste as production input as well as increase additional products. The addition of production innovation by utilizing waste and diversifying product can be promoted. The results of the calculation stated that at the world crude oil price of about 70 US $\$$ per barrel then the cost of producing raw materials of algae oil should not be more than 6.180 IDR per-liter. The addition of production innovation due to waste utilization and product diversification can increase profitability by $14.2 \%$ and $30.5 \%$, respectively, or it reduces the biodiesel production cost from 9,025 IDR per liter to 6,270 IDR per liter.
\end{abstract}

Keywords: profitability, biofuels (BBN), microalgae, biodiesel

\begin{abstract}
ABSTRAK
Dalam upaya mengurangi ketergantungan terhadap bahan bakar fosil terutama bahan bakar minyak (BBM), Pemerintah Indonesia menargetkan penggunan bahan bakar nabati (BBN) seperti bioetanol dan biodiesel sebanyak $5 \%$ pada tahun 2025 . Kendala utama dalam hal pengembangan BBN ini adalah adanya kompetisi bahan baku BBN dengan penyediaan bahan pangan, keterbatasan dalam hal sarana dan prasarana serta kendala non teknis lainnya misalnya berupa fluktuasi harga minyak mentah dunia. Bila kondisi harga minyak mentah dunia naik, maka kondisi ini akan mendorong upaya diversifikasi energi, demikian pula sebaliknya. Pada penelitian ini, dilakukan perhitungan produktifitas BBN biodiesel mikroalga dengan membandingkan harga produksinya dengan harga minyak mentah dunia. Mengacu pada hasil perbandingan biaya produksi mikroalga dengan harga minyak mentah juga dianalisis upaya peningkatan nilai profitabilitas biodiesel mikroalga dengan meningkatkan efisiensi produktivitas melalui pemanfaatan limbah sebagai input produksi dan meningkatkan produk tambahan, serta penambahan inovasi produksi dengan pemanfaatan limbah dan penganekaragaman produk. Hasil perhitungan menyatakan bahwa pada kondisi harga minyak mentah sebesar 70 US $\$ /$ barel maka biaya produksi bahan baku minyak alga tidak boleh lebih dari Rp. 6.180,-/liter. Penambahan inovasi produksi dengan pemanfaatan limbah dan penganekaragaman produk dapat meningkatkan profitabilitas sebesar $14,2 \%$ dan 30,5\% atau menurunkan biaya produksi biodiesel dari Rp. 9.025,-/liter menjadi Rp.6.270,/liter.
\end{abstract}

Kata kunci : profitabilitas, bahan bakar nabati (BBN), mikroalga, biodiesel

\section{PENDAHULUAN}

\subsection{Latar Belakang}

Salah satu upaya dari beberapa negara untuk meningkatkan kemandirian energi dan menghidari krisis energi nasionalnya adalah menyiapkan alternatif bahan bakar nabati (biofuel) yang potensial yakni berasal dari bahan biomassa mikroalga $a^{(1,2,3)}$.

Biomassa mikroalga mendapat prioritas utama, karena memiliki beberapa keunggulan komperatif dibandingkan dengan biomassa dari 
nabati lainnya. Keunggulan dari biomassa mikroalga adalah merupakan bahan bakar energi yang dapat diperbarui ${ }^{(4)}$ dan mempunyai kemampuan dalam pengurangan emisi gas $\mathrm{CO}_{2}$. Mikroalga mempunyai produktivitas mengubah $\mathrm{CO}_{2}$ menjadi karbohidrat, lemak dan protein yang jauh lebih efisien dibanding dengan tanaman darat ${ }^{(5)}$. Pertumbuhannya relatif cepat dengan waktu pembelahan selnya sekitar 3,5 jam, memerlukan air lebih sedikit dan menghasilkan bahan baku biodiesel 15-300 kali lebih cepat dibanding dengan tanaman darat ${ }^{(6)}$. Tingginya produktivitas mikroalga untuk menjadi sumber bahan biofuel yang ekonomis dan ramah lingkungan telah menarik perhatian kalangan pebisnis dan peneliti. Penelitian dalam skala laboratorium dan skala pilot plant tentang pemanfaatan mikroalga sebagai bahan baku biofuel telah banyak dilakukan ${ }^{(7,8)}$. Penanganan proses mulai dari pemurnian dan pemilihan galur, operasional produksi biomassa, pemanenan dan tahap produksi bahan bakar nabati telah dikuasai dengan baik, namun penerapannya untuk menjadi suatu kegiatan bisnis yang menggiurkan masih memerlukan penelaah lebih lanjut. Perhitungan profitabilitas dan kelayakan usaha dikaitkan dengan kompetitor sesama bahan bakar nabati dan bahan bakar minyak perlu dikaji demi keberlangsungan produksi bahan bakar nabati ini.

Pada tulisan ini akan disajikan ulasan perhitungan penentuan profitablitas dan kelayakan usaha poduksi bahan bakar nabati dari biomassa mikroalga. Basis perhitungan didasarkan pada harga minyak mentah dunia. Hasil perhitungan diharapkan dapat memberikan informasi kepada perumus kebijakan energi dan kebijakan lingkungan dalam menjadikan biomassa mikrolaga sebagai alternatif salah satu bahan produksi bahan bakar nabati di Indonesia.

\subsection{Studi Literatur}

\section{Produksi Biodiesel dari Biomassa Mikroalga}

Secara umum, produksi biodiesel dari biomassa mikrolaga dapat dikelompokkan menjadi 3 tahap sesuai dengan pentahapan pada proses produksi utama yakni tahap produksi biomassa, tahap produksi minyak alga dan tahap produksi biodiesel (Gambar 1).

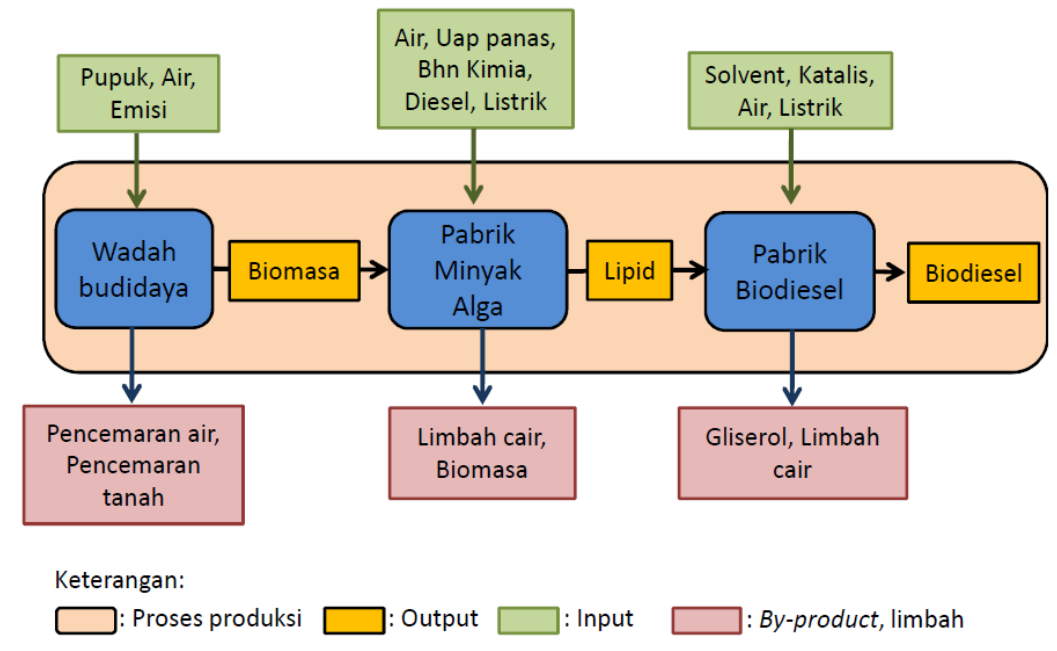

Gambar 1. Inventarisasi input, output dan produk pada proses produksi biodiesel dari biomassa mikroalga

Keberadaan input dan output dari proses produksi biodiesel akan dianalisis dan digunakan sebagai acuan perhitungan keekonomisan dan kelayakan usaha produksi bahan bakar nabati ini. Secara global, beberapa input output yang diprioritaskan antara lain:

Pada tahap sub produksi biomassa mikroalga, untuk menghasilkan produksi biomassa mikroalga dibutuhkan antara lain air sebagai media tumbuh, nutrien atau pupuk dan input gas $\mathrm{CO}_{2}$. Selain input material, pada sub tahap ini dibutuhkan energi listrik. Input energi listrik pada proses ini dipakai untuk keperluan menggerakkan pedal wheel yang berguna untuk mencampur mikroalga dalam media air agar mikroalga tidak mengendap dan kondisi media tumbuh selalu homogen. Sebagian besar kebutuhan listrik dalam proses ini juga digunakan untuk keperluan pemanenan. Pada akhir sub produksi, akan dihasilkan limbah cair berupa air sisa saringan biomassa. Air limbah ini berpotensi menimbulkan pencemaran tanah karena mengandung sisa-sisa pupuk dan biomassa yang tidak tersaring.

Pada sub produksi lipid, kebutuhan utamanya adalah energi listrik yang 
kebanyakan digunakan dalam proses pemecahan dinding sel (sonikasi). Proses sonikasi adalah proses penghancuran kulit mikroalga agar material dalam kulit lebih mudah untuk diekstrak pada proses esterifikasi. Pada sub proses ini dihasilkan juga limbah air yang berasal dari proses penyaringan biomassa yang sudah disonikasi. Limbah cair tersebut pada beberapa kasus penelitian dapat dipakai lagi dalam proses produksi selanjutnya sebagai input produksi. Limbah air bisa diresirkulasi kembali menjadi media tumbuh dengan menambahkan pupuk sesuai kebutuhan, sedangkan limbah serat biomassa dapat dipakai sebagai bahan bakar untuk pemanasan dalam pembakaran langsung atau difermentasikan sehingga menghasilkan gas metana.

Pada sub produksi yang terakhir yakni proses produksi biodiesel, bahan baku proses berupa minyak alga akan direaksikan dengan beberapa katalis kimia metanol, $\mathrm{NaOH}$ dan $\mathrm{HCl}$ untuk menghasilkan produk campuran antara biodiesel, minyak bakar dan gliserol. Proses reaksi kimia ini membutuhkan energi listrik dan uap panas. Penggunaan metanol pada proses ini relatif besar, namun bisa diminimalisasi sesuai dengan tujuan akhir produk yang diinginkan. Tingginya penggunaan metanol khususnya pada bahan minyak dari biomassa mikroalga karena tingginya residu yang harus dipisahkan berupa serat biomassa dari lipid.

\section{Prospek Pengembangan BBN Indonesia}

Pembangunan perekonomian suatu negara membutuhkan energi yang digunakan untuk memproduksi barang dalam industri seperti plastik, semen, pupuk dan lain-lain. Energi juga dibutuhkan untuk kepentingan penerangan, transportasi dan fasilitas manusia lainnya. Dengan meningkatnya populasi dan perkembangan ekonomi yang meluas, akan terjadi peningkatan penggunaan bahan bakar fosil. Peningkatan kebutuhan energi pada tiap negara ini akan meningkat seiring dengan besarnya kepentingan negara tersebut dalam meningkatkan pendapatan per kapita (GNP, gross national product) mereka. Data menunjukkan bahwa upaya peningkatan GNP akan meningkatkan pula kebutuhan akan bahan bakar fosil, dan selanjutnya akan meningkatkan pengerukan sumber daya alam yang terbatas ini. Dampak lain dari upaya pertumbuhan ekonomi adalah peningkatan konsentrasi $\mathrm{CO}_{2} \mathrm{di}$ atmosfer, dan potensi perubahan iklim yang signifikan akibat dimediasi oleh gas rumah kaca tersebut $^{(9)}$

Indonesia juga telah membuat rancangan pengembangan BBN dengan menetapkan pasokan energi nasional sebesar $5 \%$ pada tahun $2025^{(10)}$. Rancangan ini sejalan dengan prakiraan Badan Energi Internasional yang menyatakan bahwa BBN akan menyumbang $6 \%$ dari total penggunaan bahan bakar dunia pada tahun 2030.

Detail roadmap pengembangan BBN di Indonesia disajikan dalam Tabel 1 di bawah ini.

Tabel 1. Roadmap Pengembangan Biofuel 2005-2025(11)

\begin{tabular}{|l|l|l|}
\hline Produk biofuel/Tahun & \multicolumn{1}{|c|}{ 2011-2015 } & \multicolumn{1}{c|}{ 2016-2025 } \\
\hline Biodiesel & $\begin{array}{l}\text { Pemanfaatan biodiesel sebesar } \\
15 \% \text { konsumsi solar 4,52 juta } \\
\text { kilo liter }\end{array}$ & $\begin{array}{l}\text { Pemanfaatan biodiesel sebesar } \\
20 \% \text { konsumsi solar 10,22 juta } \\
\text { kilo liter }\end{array}$ \\
\hline Bioetanol & $\begin{array}{l}\text { Pemanfaatan bioetanol sebesar } \\
10 \% \text { konsumsi premium 2,78 } \\
\text { juta kilo liter }\end{array}$ & $\begin{array}{l}\text { Pemanfaatan bioetanol sebesar } \\
15 \% \text { konsumsi premium 6,28 } \\
\text { juta kilo liter }\end{array}$ \\
\hline Biooil/biokerosin & $\begin{array}{l}\text { Pemanfaatan biokerosin } \\
\text { sebesar 1,8 juta kilo liter }\end{array}$ & $\begin{array}{l}\text { Pemanfaatan biokerosin } \\
\text { sebesar 4,07 juta kilo liter }\end{array}$ \\
\hline $\begin{array}{l}\text { PPO (Processed Palm } \\
\text { Oil) untuk pembangkit } \\
\text { listrik }\end{array}$ & $\begin{array}{l}\text { Pemanfaatan PPO sebesar 0,74 } \\
\text { juta kilo liter }\end{array}$ & $\begin{array}{l}\text { Pemanfaatan PPO sebesar 1,69 } \\
\text { juta kilo liter }\end{array}$ \\
\hline Biofuel & $\begin{array}{l}\text { Pemanfaatan biofuel sebesar } \\
\text { 2\% energi mix 9,84 juta kilo liter }\end{array}$ & $\begin{array}{l}\text { Pemanfaatan biofuel sebesar } \\
2 \% \text { energi mix 22,26 juta kilo liter }\end{array}$ \\
\hline
\end{tabular}

\section{Kondisi BBM}

Tantangan perekonomian Indonesia mendatang adalah pelambatan dan ketidakpastian pertumbuhan perekonomian akibat perubahan perekonomian global yang tidak normal karena dinamikannya dipengaruhi oleh fluktuasi harga minyak dunia. Indonesia merupakan negara yang masih belum bisa melepaskan diri dari ketergantungan energi

BBM. Data Kementerian Energi dan Sumberdaya Mineral menyatakan bahwa dalam kurun waktu 30 tahun antara 1980-2010, hampir $90 \%$ energi yang digunakan untuk 
pembangunan di Indonesia berasal dari 3 sumber energi fosil utama yaitu batu bara, minyak bumi, dan gas alam ${ }^{(11)}$.
Kerentanan energi nasional Indonesia terlihat dari ketidakseimbangan antara kebutuhan dan produksi energi, seperti disajikan dalam Gambar 2 di bawah ini.

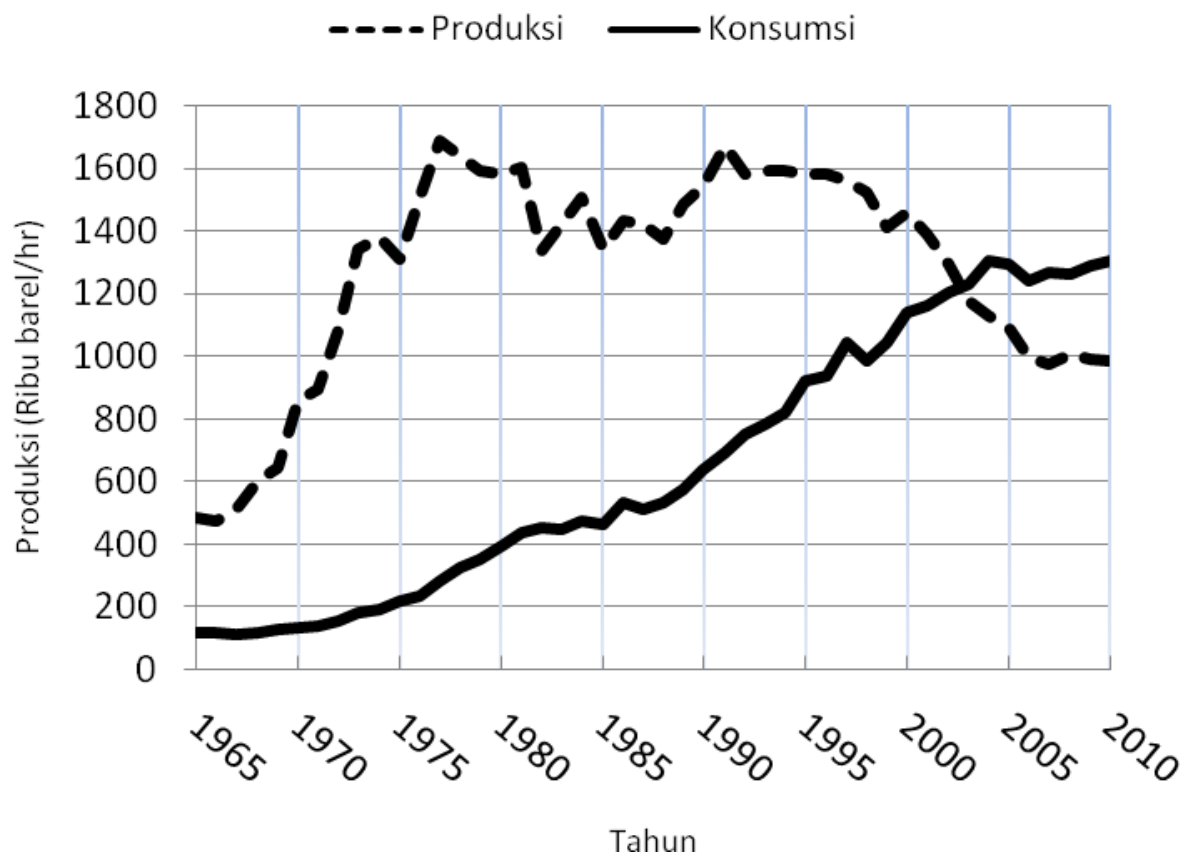

Gambar 2. Produksi dan Konsumsi BBM di Indonesia tahun 1965-2010(12)

Kapasitas produksi minyak Indonesia tidak berkembang bahkan cenderung menurun mulai tahun 1996. Pada tahun 2000 kapasitas produksi minyak sekitar 1,45 juta barel/hari dan cenderung stabil hingga sekitar satu juta barel/hari pada tahun 2008. Sebaliknya konsumsi BBM cenderung meningkat dengan pertumbuhan ekonomi dan penduduk. Kenaikan konsumsi BBM sangat tinggi dalam kurun waktu tahun 1990-2003 yakni dari 600 ribu barel/hari menjadi $1.200 \mathrm{ribu}$ barel/hari. Setelah tahun 2005 konsumsi energi cenderung stabil pada angka $1.300 \mathrm{ribu}$ barel/hari. Perbedaan antara kapasitas produksi dan konsumsi BBM memaksa Indonesia harus mengimpornya dari negara lain. Kebijakan ini membawa permasalahan baru, yakni Indonesia harus membayar harga minyak impor sesuai dengan harga minyak dunia yang cenderung tidak stabil.

\section{Biaya Produksi Biodiesel Mikroalga}

Biaya produksi biodiesel dari biomassa mikroalga menjadi pertimbangan yang utama untuk dijadikan acuan perhitungan secara finansial dalam menetapkan jenis BBN ini sebagai alternatif penyuplai bahan bakar nasional. Beberapa hasil telaah literatur menyatakan bahwa biaya produksi biodiesel mikroalga adalah sebesar 3,72 US\$/gallon ${ }^{(13)}$,
2,19 US\$/gallon ${ }^{(14)}, 2,08$ US\$/gallon ${ }^{(15)}$, dan 2,27 US\$/gallon ${ }^{(6)}$.

Untuk membedakan pengaruh penurunan biaya terhadap penambahan inovasi pada proses produksi tersebut, maka biaya produksi biodiesel juga ditelaah dengan mempertimbangkan upaya peningkatan proses produksi dalam hal penggunaan bahan material dari limbah seperti sumber media dari limbah cair dan sumber gas $\mathrm{CO}_{2}$ dari pembakaran boiler atau dari cerobong pabrik. Biaya produksi biodiesel mikroalga dengan inovasi pemanfaatan limbah tersebut dilaporkan beberapa peneliti dapat menurunkan biaya produksi sebesar 0,56 US\$/gallon ${ }^{(16)}, \quad 0,32$ US\$/galon ${ }^{(16)}, 0,53$ US\$/galon ${ }^{(17)}$.

Biaya produksi biodiesel mikroalga dapat diturunkan dengan memanfaatkan side product proses seperti serat biomassa, kandungan protein sel (asam amino) dan kandungan karbohidrat (selulosa). Beberapa peneliti menyatakan bahwa pengolahan lanjutan dari proses refining biodiesel dapat menghasilkan gliserol sebesar 1-3\% atau setara dengan 0,72 US\$/gallon ${ }^{(18,19,5)}$. 


\subsection{Tujuan Penelitian}

Profitablitas dan kelayakan usaha poduksi bahan bakar nabati Tujuan dari penelitian ini adalah untuk mengetahui dari biomassa mikroalga.

\section{BAHAN DAN METODE}

Metode penelitian dimulai dengan melakukan review literatur. Penggalian literatur meliputi topik identifikasi variabel input dan output dari proses produksi biodiesel dari biomassa mikroalga dan biaya-biaya yang digunakan selama proses tersebut. Populasi dalam penelitian ini adalah seluruh kegiatan proses produksi biodiesel dari biomassa mikroalga yang dikumpulkan dari literatur jurnal dan laporan yang terpercaya dan up to date. Sampel penelitian adalah kegiatan proses produksi biodiesel yang dipilih sesuai dengan kriteria penelitian dari seluruh data yang dikumpulkan. Sampel penelitian ditetapkan dengan metode quota sample. Data yang didapat diolah dan diintrepertasi secara manual dengan MS-Excell.

Variabel-variabel utama yang digunakan dalam penelitian ini adalah data input dan output yang diperoleh dari produksi biodiesel dari biomassa mikroalga. Data tersebut diolah untuk mendapatkan nilai profitablitas dengan mengunakan persamaan ${ }^{(6)}$

$$
\begin{aligned}
& \mathrm{C} \text { minyak alga }=6,9 \times 10^{-3} \mathrm{C} \text { minyak mentah } \\
& \text { Keterangan : } \\
& \mathrm{C}_{\text {minyak alga : harga minyak alga (US } \$ / \text { liter) }} \\
& \left.\mathrm{C}_{\text {minyak mentah: }} \text { harga mentah (US } \$ / \mathrm{barell}\right)
\end{aligned}
$$

Data tentang variabel input dan output dari proses produksi biodiesel dari biomassa juga dikembangkan menjadi 3 simulasi, data utama proses produksi biodiesel dijadikan sebagai data kontrol. Sebagai pembanding pertama digunakan variabel inovasi pada proses produksi dengan pemanfaatan limbah cair dan emisi gas $\mathrm{CO}_{2}$. Sedangkan sebagai pembanding kedua digunakan inovasi pada pengembangan side product menjadi produk yang bernilai ekonomis.

\section{HASIL DAN PEMBAHASAN}

\subsection{Profitabilitas Biodiesel Mikroalga}

Perkiraan harga bahan baku minyak alga yang memenuhi kreteria ekonomi sehingga komponen harga tersebut dapat menunjang keberlangsungan industri biodiesel digambarkan dalam gambar di bawah ini.

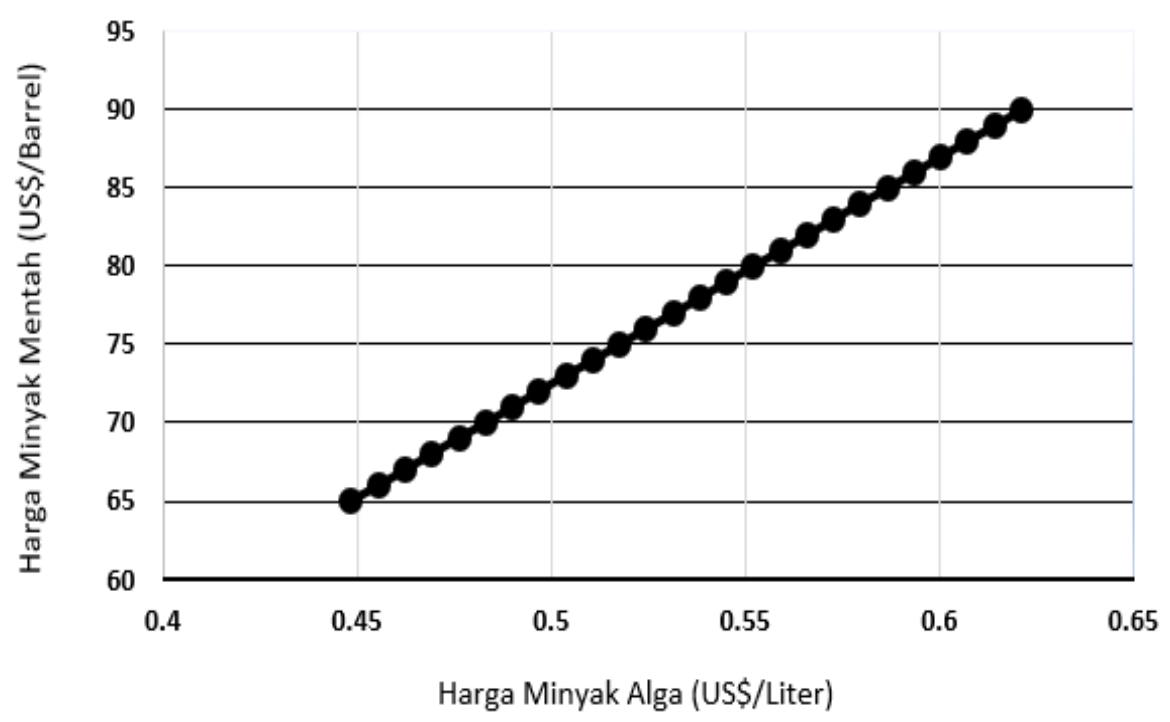

Gambar 3. Hubungan Antara Harga Minyak Alga dari Biomassa Mikrolaga dengan Harga Minyak Mentah

Perhitungan profitabilitas biodiesel mikroalga dilakukan dengan membandingkan biaya produksi minyak alga dengan biaya produksi minyak mentah. Berdasarkan harga minyak mentah sekitar 70 US $\$$ barrel, maka harga realitistis dari minyak alga adalah sekitar 0,483 US\$/liter atau Rp. 6.180,-/liter. Semakin rendah harga minyak mentah akan berakibat pada semakin rendah pula patokan harga produksi minyak alga. Peningkatan harga produksi bahan baku minyak alga di atas harga realistis tersebut menyebabkan ketimpangan biaya produksi yang berunjung pada ketidakstabilan proses produksi biodiesel mikroalga. 


\subsection{Peningkatan Profitabilitas Biodiesel Mikroalga}

Seperti telah disebutkan bahwa berdasarkan beberapa kajian literatur menyatakan bahwa biaya biodiesel mikroalga adalah berkisar antara 2,08 US\$/galon ${ }^{(15)}$, hingga 3,72 US $\$ /$ galon $^{(13)}$, atau 0,550 US $\$$ /liter hingga 0,983 US $\$$ /liter. Biaya tersebut dapat diturunkan melalui inovasi pemanfaatan limbah yang berhasil menurunkan biaya produksi sebesar 0,56 US $\$ /$ galon $^{(16)}$ atau 0,148 US $\$ /$ iter hingga, 0,32 US $\$ /$ galon $^{(16)}$ atau 0,085 US $\$ /$ liter. Dengan demikian potensi biaya produksi setelah melalui inovasi pemanfaatan limbah menjadikan harga atau biaya biodiesel mikroalga menjadi $(0,550-0,148)$ US\$/liter atau 0,402 US $\$ /$ iter hingga $(0,983-0,148)$ atau 0,835 US $\$ /$ liter. Seandainya ini menjadi dasar dari biaya atau harga biodiesel mikroalga yang ada saat ini yaitu antara 0,402 US $\$$ /iter hingga 0,835 US\$/liter, maka dengan menggunakan persamaan $^{(6)}$ tingkat profitabilitas biodiesel mikroalga dilihat dari harga minyak mentah adalah antara 58,26 US\$/barel hingga 121,01 US\$/barel. Namun apabila tidak menggunakan inovasi pemanfaatan limbah, maka tingkat profitabilitas biodiesel mikroalga dilihat dari harga minyak mentah adalah antara 79,71 US $\$$ /barel hingga 142,46 US\$/barel.

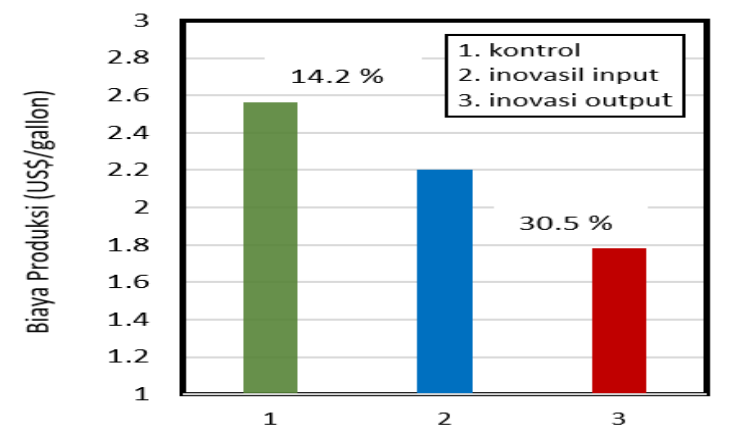

Gambar 4. Peningkatan Profitabilitas Biodiesel Mikroalga

Dengan demikian profitabilitas biodiesel mikroalga dari berbagai kajian yang ada saat ini akan berkisar apabila harga minyak antara 58,26 US $\$$ barel hingga 121,01 US $\$ /$ barel dengan menerapkan inovasi pemanfaatan limbah, atau dengan harga minyak antara 79,71 US\$/barrel hingga 142,46 US\$/barel tanpa inovasi pemanfaatan limbah. Dilihat perkembangan harga minyak mentah dalam 70 tahun terakhir menurut data dari macrotrends.net harga paling rendah 15,86 US\$/barel di tahun 1946 hingga saat ini sekitar 60 US $\$$ /barel. Fluktuasi harga yang tinggi dicapai tahun 1980 yaitu 120,28 US\$/barel dan tahun 2008 yaitu 157,73 US\$/barel. Mengingat fluktuasi harga minyak fosil yang suatu saat nantinya akan habis, maka potensi biodiesel termasuk mikroalga sebagai bahan bakar terbarukan akan menjadi alternatif terbaik untuk terus menerus melakukan inovasi sebagai solusi pemenuhan kebutuhan energi di masa mendatang. Dengan demikian biodiesel mikroalga akan menjadi salah satu alternatif untuk dikembangkan sabagai energi terbarukan mengingat bahwa harga tertinggi yang pernah dialami yaitu antara 120,28 US $\$$ /barel hingga 157 US\$/barrel sudah memenuhi ruang profitabilitas biodiesel mikroalga.

\section{KESIMPULAN}

Profitabilitas biomassa mikroalga sebagai bahan baku bahan bakar nabati dapat ditentukan dengan mempertimbangkan harga minyak mentah yang menjadi kompetitornya. Pada kondisi harga minyak mentah sebesar 70 US $\$$ /barel maka biaya produksi bahan baku minyak alga tidak boleh lebih dari Rp. 6.180,/liter. Profitablitas biodiesel mikroalga dapat ditingkatkan dengan meningkatkan efisiensi produktivitas melalui pemanfaatan limbah sebagai input produksi dan meningkatkan produk tambahan. Penambahan inovasi produksi dengan pemanfaatan limbah dan penganekaragaman produk dapat meningkatkan profitabilitas sebesar $14,2 \%$ dan $30,5 \%$ atau menurunkan biaya produksi biodiesel dari Rp. 9.025,-/liter menjadi Rp.6.270,-/liter. Sedangkan apabila dilihat dari harga minyak mentah maka profitabilitas biodiesel mikroalga berkisar antara 58,26 US $\$$ /barel hingga 121,01 US $\$ /$ barel dengan menerapkan inovasi pemanfaatan limbah, atau dengan harga minyak antara 79,71 US\$/barel hingga 142,46 US $\$$ /barel tanpa inovasi pemanfaatan limbah. Melihat kenyataan harga minyak saat ini yang berfluktuasi serta cenderung akan meningkat, maka potensi biodiesel termasuk mikroalga sebagai bahan bakar terbarukan akan menjadi alternatif terbaik untuk terus menerus melakukan inovasi sebagai solusi pemenuhan kebutuhan energi di masa mendatang. Dengan demikian biodiesel mikroalga akan menjadi salah satu alternatif untuk dikembangkan sebagai energi terbarukan mengingat bahwa harga tertinggi yang pernah dialami yaitu antara 120,28 US $\$$ /barel hingga 157 US\$/barel sudah memenuhi ruang profitabilitas biodiesel mikroalga.

\section{PERSANTUNAN}

Kementerian Riset dan Teknologi, atas bantuan pembiayaan beasiswa bagi peneliti untuk melaksanakan penelitian ini. Ucapan terima kasih juga ditujukan kepada Dr. Joko Prayitno Susanto atas bantuan telaah dan masukan konsep hingga penulisan makalah ini. 


\section{DAFTAR PUSTAKA}

1. Demirbas, A., \& Demirbas, M.F. (2011). Importance of Algal Oil as a Source of Biodiesel. Energy Convers Manage, 52, 163 -170 .

2. Halim, R., Danquah, M.K., \& Webley P.A. (2011). Oil Extraction from Microalgae for Biodiesel Production. Biores Technol, 102, $178-185$.

3. Khoo, H.H., Tan, R.B.H., \& Tan, Z.H. (2009). GHG intensities from the life cycle of conventional fuel and biofuels. Air Pollution, 17, 329- 340.

4. Jorquera, O., Kiperstok, A., Sales, E.A., Embirucu, M., Ghirardi, M.L. (2010). Comparative Energy Life-Cycle Analyses of Microalgal Biomasa Production in Open Ponds and Photobioreactors. Bioresour Technol, 101, 1406-1413.

5. Scott, S.A., Davey, M.P., Dennis, J.S., Horst, I., Howe, C.J., Lea-Smith, D J., and Smith, A.G. (2010). Biodiesel from Algae: Challenges and Prospects. Current Opinion in Biotecnology, 21, 227-286.

6. Chisti Y. (2007). Biodiesel from Microalgae. Biotechnol Adv., 25, 294-306.

7. Batan, L., Quinn, J., Willson, B., Bradley, T., (2010). Net Energy and Greenhouse Gas Emission Evaluation of Biodiesel Derived from Microalgae. Environ. Sci. Technol, 44, 7975-7980.

8. Lardon, L., Helias, A., Sialve, B., Steyer, J.P., Bernard, O. (2009). Life Cycle Assessment of Biodiesel Production from Microalgae. Environmental science and technology, 43, 6475-6481.

9. Parry ML, Canziani OF, Palutikof JP, van der Linden PJ, Hanson CE. (2007). Climate Change 2007: Impacts, Adaptation and Vulnerability Contribution of Working Group II Intergovernmental Panel on Climate Change, Working Group. Cambridge University Press; Cambridge, UK.

10.Anonimous. (2006). Kebijakan Energi Nasional. Peraturan Presiden No 5 Tahun 2006

11.Kementerian Energi Sumberdaya Mineral. (2015). Handbook of Energy and Economic Statistic of Indonesia. Center for Data and Information on Energy and Mineral Resources Ministry of Energy and Mineral Resources, p121.
12.BP. (2017). BP Statistical Review Full Report Workbook 2008. www.bp.com. Diakses pada 8 Desember 2017.

13.Davis, R., Aden, A., \& Pienkos, P. T. (2011). Techno-economic analysis of autotrophic microalgae for fuel production. Applied Energy, 88(10), 3524-3531. http://doi.org/10.1016/i.apenergy.2011.04.01 8

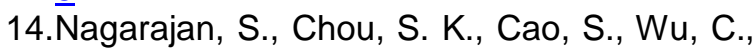
\& Zhou, Z. (2013). An updated comprehensive techno-economic analysis of algae biodiesel. Bioresource Technology, 145 , 150-6. http://doi.org/10.1016/j.biortech.2012.11.108

15.Benemann, J.R., \& Oswald, W.J. (1996). Systems and economic analysis of microalgae ponds for conversion of $\mathrm{CO}$ \{sub $2\}$ to biomass. Final report. United States. doi:10.2172/493389

16.Rupiper, A. (2016). Potential for biofuel production from algae based wastewater treatment in California: Can algal biofuels be cost-competitive with traditional petroleum based diesel?.

17.Maity, J. P., Bundschuh, J., Chen, C.-Y., \& Bhattacharya, P. (2014). Microalgae for third generation biofuel production, mitigation of greenhouse gas emissions and wastewater treatment: Present and future perspectives A mini review. Energy, 78, 104-113. http://doi.org/10.1016/j.energy.2014.04.003

18. Murthy, G.S. (2010). Life Cycle Analysis of Algae Biodiesel. Int J Life Cycle Assess. 15, 704-714.

19.Stephenson, A.L., Kazamia, E., Dennis, J.S., Howe, C.J., Scot, A.A., Smith, A.G. (2010). Life Cycle Assessment of Potential Algal Biodiesel Production in the United Kingdom: A Comparison of Raceways and Air-Lift Tubular Bioreactors. Energy Fuels., 24, 4062-4077.

20.Energy Information Administration. International Energy Outlook. (2009). Vol. 284. EIA; DC, USA.

21.Kementerian Energi Sumberdaya Mineral. (2012). Handbook of Energy and economic Statistic of Indonesia.Center for Data and Information on Energy and Mineral Resources Ministry of Energy and Mineral Resources, p121 
